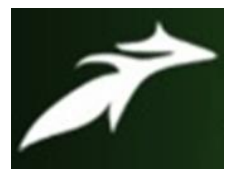

S.G.J David Son et al, International Journal of Advances in Agricultural Science \& Technology,

Vol.8 Issue.11, November-2021, pg. 1-11

ISSN: 2348-1358

Impact Factor: 6.057

NAAS Rating: 3.77

\title{
A Study on Communication Behaviour of Extension Personnel of Prakasam District of Andhra Pradesh
}

\author{
S.G.J David Son \\ Msc. Ag.(Agricultural Extension \& Communication), SHUATS (Prayagraj) \\ Dipak Kumar Bose \\ Associate Professor, Department of Agricultural Extension and Communication, SHUATS, Prayagraj \\ Jahanara \\ Professor and Head, Department of Agricultural Extension and Communication, SHUATS, Prayagraj, Uttar Pradesh, India \\ DOI: 10.47856/ijaast.2021.v08i11.001
}

\begin{abstract}
Successful communication is the main job of an extension worker. He cannot expect change among farmers unless he is able to communicate effectively to them. This entails the extension personal to have thorough understanding of communication process. This study will be helpful in identifying important variables of extension personnel affecting their communication process. Prakasam District of Andhra Pradesh was selected by purposive random sampling. The study was conducted in 7 mandal's which were selected randomly. Respondents were Agricultural officers, agricultural extension officers, village agricultural assistants and village horticultural assistants. The total sample size for the study were 120 extension personnel. majority of the respondents were female, young aged, having high educational status, with low annual income, job experience and training exposure. Perceived work load was high, medium level of job satisfaction and low level of Innovativeness and medium level of achievement motivation and medium level of communication behaviour was observed. The findings of overall communication behaviour of extension personnel indicate that there is need to increase the communication behaviour from medium to high through suitable training programs on latest Communication technologies and communication skills, providing needed literature.
\end{abstract}

Keywords: Extension Personnel, Communication behaviour 


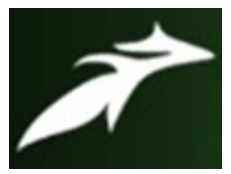

S.G.J David Son et al, International Journal of Advances in Agricultural Science \& Technology, Vol.8 Issue.11, November-2021, pg. 1-11

ISSN: 2348-1358

Impact Factor: 6.057

NAAS Rating: 3.77

\section{Introduction}

Extension is a process of getting information to people and then assisting those people to utilize the information. Successful communication is the main job of an extension worker. He cannot expect change among farmers unless he is able to communicate effectively to them. This entails the extension personal to have thorough understanding of communication process.

Extension has to play a vital role in promoting adoption of technologies in primary and secondary agriculture in India. It is more complex considering the small holding size of farm, resource poor farmers, dry land farming, price fluctuations, inadequate market facilities, natural vagaries like flood, drought, etc. Therefore, communication for achieving efficiency in primary and secondary agriculture is a challenging task.(Gowda, 2020)

This study will be helpful in identifying important variables of extension personnel affecting their communication process. It will be quiet befitting to provide useful guidelines to promote the functioning of extension personnel.

To have effective transfer of technology among the research system and the farming community, the extension personnel had to play a crucial role. The circle of technology transfer process cannot be completed unless and until effective and efficient role played by an extension personnel. For this purpose the extension personnel ought to be effective information seekers to perform their role as 'facilitators' for accessing farm inputs, advisory services and markets to the farming community. Grass root extension functionaries are the direct link for bridging the communication gap between the agricultural researchers and the farmers. In order to perform this role effectively and efficiently, these agricultural extension personnel must have up to date agricultural information. To achieve meaningful growth in agricultural sector, there is need for a comprehensive and well-articulated agricultural extension programme which ensures adequate and timely delivery of services to farmers.(Tekale, 2019)

\section{Research methodology}

This section describes the approches and methods employed for data collection and analysis. Prakasam District of Andhra Pradesh was selected by purposive random sampling. The study was conducted in 7 Mandal's which were selected randomly. Respondents were Agricultural officers, agricultural extension officers, village agricultural assistants and village horticultural 


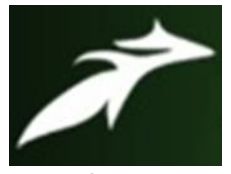

S.G.J David Son et al, International Journal of Advances in Agricultural Science \& Technology,

Vol.8 Issue.11, November-2021, pg. 1-11

ISSN: 2348-1358

Impact Factor: 6.057

NAAS Rating: 3.77

assistants. The total sample size for the study were 120 extension personnel. Descriptive research design was used for present study. The selected independent variables were Age, Education, Annual Income, Job Experience, Training Exposure, Perceived Work Load, Job Satisfaction, Innovativeness and Achievement Motivation. The dependent variable of the study was the Communication Behaviour of the Extension personnel. The primary data was collected using a well structured interview schedule developed according to specific objectives of the study. The data was analysed by using appropriate statistical tools in order to draw logical conclusions.

\section{Results and Discussion}

Table 1: Profile of the respondents

\begin{tabular}{|c|c|c|c|c|}
\hline S.no & Profile of the responde & & Frequency & Percentage \\
\hline \multirow[t]{3}{*}{1} & \multirow[t]{3}{*}{ Age } & Young(<35 years) & 60 & 50 \\
\hline & & Middle (35-55 years) & 55 & 45.83 \\
\hline & & Old (>55 years) & 06 & 5 \\
\hline \multirow[t]{6}{*}{2} & \multirow{6}{*}{$\begin{array}{c}\text { Educational } \\
\text { status }\end{array}$} & B.Sc. Agriculture & 26 & 21.66 \\
\hline & & B.Sc. Horticulture & 34 & 28.33 \\
\hline & & M.Sc. Agriculture & 04 & 3.33 \\
\hline & & Diploma (Ag.) & 50 & 41.66 \\
\hline & & B.Tech. (Ag.) & 04 & 3.33 \\
\hline & & Others & 02 & 1.7 \\
\hline \multirow[t]{2}{*}{3} & \multirow[t]{2}{*}{ Annual Income } & Low (<2.5 lakhs) & 59 & 49.1 \\
\hline & & Medium (2.5- 5 lakhs) & 48 & 40 \\
\hline
\end{tabular}




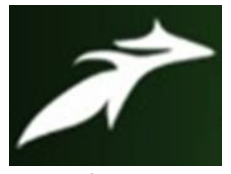

S.G.J David Son et al, International Journal of Advances in Agricultural Science \& Technology,

Vol.8 Issue.11, November-2021, pg. 1-11

ISSN: 2348-1358

Impact Factor: 6.057

NAAS Rating: 3.77

\begin{tabular}{|c|c|c|c|c|}
\hline & & High(> 5 lakhs) & 13 & 10.83 \\
\hline \multirow[t]{3}{*}{4} & \multirow[t]{3}{*}{ Job experience } & Low (1-5 years) & 58 & 48.44 \\
\hline & & Medium (6-10 years) & 55 & 45.83 \\
\hline & & High (11-15 years) & 07 & 5.83 \\
\hline \multirow[t]{3}{*}{5} & \multirow[t]{3}{*}{ Training exposure } & Low(1-7) & 60 & 50 \\
\hline & & Medium(8-13) & 50 & 41.66 \\
\hline & & $\operatorname{High}(14-19)$ & 10 & 8.33 \\
\hline \multirow[t]{3}{*}{6} & \multirow[t]{3}{*}{ Perceived Work Load } & $\operatorname{Low}(<10.8)$ & 11 & 9.16 \\
\hline & & Medium (10.8-11.6) & 04 & 3.33 \\
\hline & & High (>12.4) & 105 & 87.5 \\
\hline \multirow[t]{3}{*}{7} & \multirow[t]{3}{*}{ Job satisfaction } & Low(<18) & 07 & 5.83 \\
\hline & & Medium (19) & 84 & 70 \\
\hline & & $\mathrm{High}(>20)$ & 29 & 24.16 \\
\hline \multirow[t]{3}{*}{8} & \multirow[t]{3}{*}{ Innovativeness } & Low $(>13.25)$ & 48 & 40 \\
\hline & & Medium (13.25-14.25) & 42 & 35 \\
\hline & & High (>15.75) & 30 & 25 \\
\hline \multirow[t]{3}{*}{9} & \multirow[t]{3}{*}{ Achievement motivation } & Low (>11.76) & 37 & 30.83 \\
\hline & & Medium (11.75-12.5) & 60 & 50 \\
\hline & & High (>13.25) & 23 & 19.16 \\
\hline
\end{tabular}




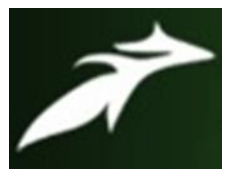

S.G.J David Son et al, International Journal of Advances in Agricultural Science \& Technology,

Vol.8 Issue.11, November-2021, pg. 1-11

ISSN: 2348-1358

Impact Factor: 6.057

NAAS Rating: 3.77

It can be concluded from the above table that the detailed analysis of profile of extension personnel indicated that Majority of respondents $50 \%$ belonged to the age group of below 35 years, more than one third (41.7\%) of the respondents had Diploma in Agricultural education, In case of annual Income, majority (49.1\%) of respondents belongs to the Low level of annual Income similar to finding of Mundhe(2016). Nearly half of the respondents $48.44 \%$ belongs to low level of job experience, This finding is similar to Hashemi(2014).

Half of the respondents $50 \%$ had low level of training exposure. Majority of the respondents $87.5 \%$ had high work load. This finding is similar to Babu (2018). With regards to satisfaction of job, majority of the respondents $70 \%$ had medium level of job satisfaction. This finding is similar to Kabir and Roy (2015). In case of Innovativeness, majority of the respondents I.e $40 \%$ had low category of Innovativeness. Half of the respondents $50 \%$ had medium level of achievement motivation.

\section{Communication Behaviour of the Respondents}

Communication behaviour of the extension personnel are the various activities undertaken by them for the development and dissemination of the improved agricultural information. The concept of communication behaviour was broken into three main components namely Information Input Behaviour, Information Processing Behaviour and Information Disseminating Behaviour. The communication Behaviour is the aggregate of scores obtained on all these three components.

Table2 Distribution of the respondents according to their communication behaviour.

$(n=120)$

\begin{tabular}{|l|l|l|l|}
\hline S.No & Category & Frequency & Percentage \\
\hline 1 & Low $(<80)$ & 17 & 14.00 \\
\hline 2 & Medium (80-84) & 81 & 68.00 \\
\hline 3 & High( 84-88) & 22 & 18.00 \\
\hline & Total & 120 & 100.00 \\
\hline
\end{tabular}




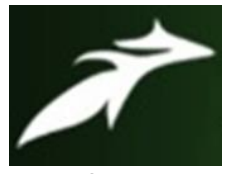

S.G.J David Son et al, International Journal of Advances in Agricultural Science \& Technology,

Vol.8 Issue.11, November-2021, pg. 1-11

ISSN: 2348-1358

Impact Factor: 6.057

NAAS Rating: 3.77

The data presented from the table 4.2 Shows that majority of the extension personnel i.e $68 \%$ had medium level, followed by $18 \%$ of High level and $14 \%$ of low level of communication behaviour.

\subsection{Information Input Behaviour.}

Table 2.1 Distribution of respondents according to information input behaviour.

\begin{tabular}{|l|l|l|l|l|l|l|l|}
\hline S.No & \multirow{2}{*}{ Sources of information } & \multicolumn{2}{l}{ Frequently } & \multicolumn{2}{l}{ Occasionally } & \multicolumn{2}{l|}{ Never } \\
\cline { 3 - 9 } & & F & P & F & P & F & P \\
\hline 1 & Considering farmers feedback & 100 & 83.33 & 20 & 16.66 & 00 & 00 \\
\hline 2 & Consulting superior officers & 120 & 100 & 00 & 00 & 00 & 00 \\
\hline 3 & Discussing with colleagues & 110 & 91.66 & 10 & 8.33 & 00 & 00 \\
\hline 4 & $\begin{array}{l}\text { Getting ideas from group } \\
\text { discussion }\end{array}$ & 60 & 50 & 60 & 50 & 00 & 00 \\
\hline 5 & Reading magazines & & & & & & \\
\hline 6 & Reading newspaper articles & 70 & 58.33 & 30 & 25 & 20 & 16.66 \\
\hline 7 & Attending training programs & 30 & 25 & 90 & 75 & 00 & 00 \\
\hline 8 & Visiting Agri websites & 45 & 37.5 & 75 & 62.5 & 00 & 00 \\
\hline 9 & Social media (whatsapp etc) & 120 & 100 & 00 & 00 & 00 & 00 \\
\hline 10 & Mobile apps on Agriculture & 120 & 100 & 00 & 00 & 00 & 00 \\
\hline
\end{tabular}

The data presented from table 2.1. indicates that majority of the sources I.e $100 \%$ of information were from consulting superior officers, social media, mobile apps related to agriculture, followed by $91.6 \%$ discussing with colleagues, $83.3 \%$ considering farmers feedback. 


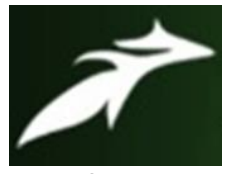

S.G.J David Son et al, International Journal of Advances in Agricultural Science \& Technology,

Vol.8 Issue.11, November-2021, pg. 1-11

ISSN: 2348-1358

Impact Factor: 6.057

NAAS Rating: 3.77

\subsection{Information Processing Behaviour.}

Information processing behaviour referred to all the activities performed by the Extension personnel for evaluation and transformation of the information.

\subsubsection{Information Evaluation}

\begin{tabular}{|c|c|c|c|c|c|c|c|}
\hline \multirow[t]{2}{*}{ S.no } & \multirow[t]{2}{*}{ Statement } & \multicolumn{2}{|c|}{ Frequently } & \multicolumn{2}{|c|}{ Occasionally } & \multicolumn{2}{|c|}{ Never } \\
\hline & & $\mathbf{F}$ & $\mathbf{P}$ & $\mathbf{F}$ & $\mathbf{P}$ & $\mathbf{F}$ & $\mathbf{P}$ \\
\hline 1 & Accept it unreservedly & 80 & 66.66 & 30 & 25 & 10 & 8.33 \\
\hline 2 & $\begin{array}{l}\text { Discuss with progressive } \\
\text { farmers }\end{array}$ & 120 & 100 & 00 & 00 & 00 & 00 \\
\hline 3 & $\begin{array}{l}\text { Judging in light of past } \\
\text { experience }\end{array}$ & 40 & 33.33 & 80 & 66.66 & 00 & 00 \\
\hline 4 & Discussing with colleagues & 120 & 100 & 00 & 00 & 00 & 00 \\
\hline 5 & $\begin{array}{l}\text { Considering economical and } \\
\text { local flexibilities }\end{array}$ & 120 & 100 & 00 & 00 & 00 & 00 \\
\hline 6 & $\begin{array}{l}\text { Judging by degree of } \\
\text { complexity }\end{array}$ & 55 & 45.83 & 50 & 41.67 & 15 & 12.5 \\
\hline
\end{tabular}

It was observed from the table 2.2.1 that extension personnel evaluate information $100 \%$ by discussing with colleagues, progressive farmers and considering economical and local flexibilities followed by $66.6 \%$ judging in the light of past experience and accepting unreservedly, $45.83 \%$ judging by degree of complexity. 


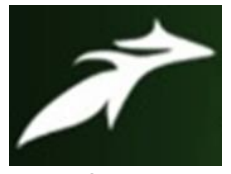

S.G.J David Son et al, International Journal of Advances in Agricultural Science \& Technology,

Vol.8 Issue.11, November-2021, pg. 1-11

ISSN: 2348-1358

Impact Factor: 6.057

NAAS Rating: 3.77

\subsubsection{Information Transformation}

\begin{tabular}{|l|l|l|l|l|l|l|l|}
\hline \multirow{2}{*}{ S.NO } & \multirow{2}{*}{ Statements } & \multicolumn{2}{l}{ Frequently } & \multicolumn{2}{l}{ Ocassionally } & \multicolumn{2}{l|}{ Never } \\
\cline { 3 - 8 } & & F & P & F & P & F & P \\
\hline 1 & $\begin{array}{l}\text { Preparing lectures in local } \\
\text { language }\end{array}$ & 20 & 16.66 & 100 & 83.33 & 00 & 00 \\
\hline 2 & Preparing charts, posters etc & 110 & 91.66 & 10 & 8.33 & 00 & 00 \\
\hline 3 & Adding personal experience & 30 & 25 & 90 & 75 & 00 & 00 \\
\hline 4 & Adding success stories & 110 & 91.66 & 10 & 8.33 & 00 & 00 \\
\hline 5 & Preparing written materials & 10 & 8.33 & 110 & 91.66 & 00 & 00 \\
\hline 6 & Demonstrations & 60 & 50 & 60 & 50 & 00 & 00 \\
\hline
\end{tabular}

The data presented in the table 2.2.3 indicates that majority of the extension personnel transform the information $91.6 \%$ by preparing charts posters, written materials, adding success stories, followed by $83 \%$ preparing lectures in local languages and $50 \%$ by result demonstrations.

2.2.3 Information Dissemination Behaviour

\begin{tabular}{|l|l|l|l|l|l|l|l|}
\hline S.no & Communication & \multicolumn{2}{l}{ Frequently } & \multicolumn{2}{l}{ Occasionally } & \multicolumn{2}{l|}{ Never } \\
\cline { 3 - 8 } & & F & P & F & P & F & P \\
\hline 1 & Farm and house visits & 90 & 75 & 30 & 25 & 00 & 00 \\
\hline 2 & Conducting field days & 95 & 79.16 & 25 & 20.83 & 00 & 00 \\
\hline 3 & Results demonstrations & 18 & 15 & 102 & 85 & 00 & 00 \\
\hline 4 & Campaigns & 21 & 17.5 & 99 & 82.5 & 00 & 00 \\
\hline 5 & Sending SMS & 115 & 95.83 & 4.16 & 12.5 & 00 & 00 \\
\hline
\end{tabular}




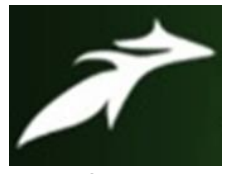

S.G.J David Son et al, International Journal of Advances in Agricultural Science \& Technology,

Vol.8 Issue.11, November-2021, pg. 1-11

ISSN: 2348-1358

Impact Factor: 6.057

NAAS Rating: 3.77

\begin{tabular}{|l|l|l|l|l|l|l|l|}
\hline 6 & Phone calls & 117 & 97.5 & 03 & 2.5 & 00 & 00 \\
\hline 7 & Farmers training programs & 30 & 25 & 90 & 75 & 00 & 00 \\
\hline 8 & Fim shows & 00 & 00 & 20 & 16.66 & 100 & 83.33 \\
\hline 9 & Posters, pamphlets & 80 & 66.66 & 40 & 33.33 & 00 & 00 \\
\hline
\end{tabular}

It can be concluded from the table that $97.5 \%$ was through phone calls, $95.83 \%$ through sending SMS, $85 \%$ by result demonstrations, $82.5 \%$ by campaigns, $79.16 \%$ by conducting field days and $75 \%$ by farm and house visits and $66.6 \%$ through posters and pamphlets.

3) Relationship Between Profile Of The Respondents With Communication Behaviour.

Table 3: correlation between the profile characteristics and communication behaviour $(n=120)$

\begin{tabular}{|l|l|l|}
\hline S.no & Profile characteristics & 'r' value \\
\hline 1 & Age & $0.348^{* *}$ \\
\hline 2 & Educational status & $0.317^{* *}$ \\
\hline 3 & Annual Income & $0.225^{*}$ \\
\hline 4 & Job experience & $0.391^{* *}$ \\
\hline 5 & Training exposure & $0.263^{*}$ \\
\hline 6 & Perceived work load & $-0.496^{*}$ \\
\hline 7 & Job satisfaction & $0.977^{* *}$ \\
\hline 8 & Innovativeness & $0.123 \mathrm{NS}$ \\
\hline 9 & Achievement motivation & $0.900^{* *}$ \\
\hline
\end{tabular}

$* * 0.01 \%$ level of Significant

$* 0.05 \%$ level of Significant.

NS - Non Significant. 


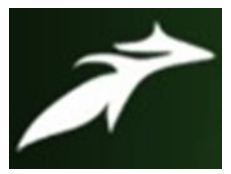

S.G.J David Son et al, International Journal of Advances in Agricultural Science \& Technology, Vol.8 Issue.11, November-2021, pg. 1-11

ISSN: 2348-1358

Impact Factor: 6.057

NAAS Rating: 3.77

The data presented in the table 3 indicates that variables such as Age, Education, Income, Job Experience, Training Exposure, Job satisfaction and Achievement Motivation had positive and significant relationship with communication behaviour. Perceived Work Load was negatively correlated with the dependent variable. There exists positive and non significant relation between Innovativeness and communication behaviour. There exists positive and non significant relation between Innovativeness and communication behaviour. Age $\left(r=0.348^{* *}\right)$, Educational status $\left(r=0.317^{* *}\right)$, Job experience $\left(r=0.391^{* *}\right)$ of respondents had a positive and significant relationship with communication behaviour at $0.01 \%$ level of significant.Annual Income $\left(r=0.225^{*}\right)$,Training exposure $\left(r=0.263^{*}\right)$ of the respondents had positive and correlation at $0.05 \%$ level of significant. It implies that as the these variables increases, communication behaviour of the respondent also increases. Perceived Work Load $(r=-0.496 *)$ was negatively and significantly correlated with communication behaviour. This means the more the perceived work load, the less would be the communication behaviour of extension personnel.These findings was similar to the findings of Babu (2018).Job satisfaction( $r=0.977^{* *}$ ) and achievement motivation $\left(r=0.900^{*}\right)$ were positively and (very highly) significant with communication behaviour of the respondents.

\section{CONCLUSION}

It is concluded from that majority of the respondents were female, young aged, having high educational status, with low annual income, job experience and training exposure .Perceived work load was high, medium level of job satisfaction and low level of Innovativeness and medium level of achievement motivation and medium level of communication behaviour was observed.Variables such as Age, Education, Income, Job Experience, Training Exposure, Job satisfaction and Achievement Motivation had positive and significant relationship with communication behaviour. Perceived Work Load was negatively correlated with the dependent variable. There exists positive and non significant relation between Innovativeness and communication behaviour. 


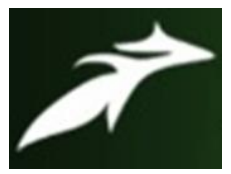

S.G.J David Son et al, International Journal of Advances in Agricultural Science \& Technology, Vol.8 Issue.11, November-2021, pg. 1-11

ISSN: 2348-1358

Impact Factor: 6.057

NAAS Rating: 3.77

\section{REFERENCES}

[1]. Babu, P. R., (2018): A study on Communication behaviour of extension personal of Andhra Pradesh, Ph.D. thesis. Acharya N.G. Ranga Agricultural University.

[2]. Baruah, A., and Mohan,M.G.,(2021) Exploring the ICT Preferences of Personnel from Agricultural Extension Organizations in the Northeastern Region of India, Asian Journal of Agriculture and Development, Volume 18 Number 1,June 2021.

[3]. Gowda, N. K, (2020). Concepts and principles of Agricultural Extension Education, Hand book of agricultural extension, Indian Council of Agricultural Research.

[4]. Hashemi, Haji, Zahra Rad, Pezeshki Rad, Gholamreza Mohammad, and Chizari Mohammad. 2014. "Factors Influencing the Use of and Attitude of Using Information and Communication Technologies (ICTs) in Agricultural Extension, a Study in the Isfahan Province of Iran." International Journal of Agricultural Management and Development 4(1): 1-10. DOI: 10.22004/ag.econ.210358

[5]. Jahagirdhar, K. A., Balasubramanya, A.S., (2019) A study on communication behaviour of extension personnel,Karnataka. J. Agric. Sci.,23 (2) : (384-385) 2010.

[6]. Kabir and Debashis Roy (2015) Preferences of ICT Tools by the Upazila Agriculture Officers (UAOs) for the Information Exchange in Bangladesh March 2015. Agriculture Forestry and Fisheries 4(2):59-65. DOI:10.11648/j.aff.20150402.16

[7]. Kumar Arvinder, Kher, S.K., Nanda Rakesh, Sharma Akash, Rizvi, S.E.H., and Ahmad Hafeez.(2017). Information source utilisation pattern of Horticulture Extension Personnel for Seeking and Dissemination of Horticultural Technology in Jammu Region of Jammu and Kashmir, India, Int.J.Curr.Microbiol.App.Sci. $6(11)$.

[8]. Mundhe, D. V.; Gaikwad, S. S.; Patil, R. L. Preferences of extension personnel about different aspects of training. International Journal of Tropical Agriculture 2016 Vol.34 No.7 pp.2097-2101 ref.7

[9]. Raksha and Meera (2015). Determinants of ICTs in agricultural extension system, Journal of Extension education. 15(1): 1-7

[10].Tekale, V.S., Parashuramkar, S.G., and Sarnaik, S.D. (2019)Communication Behavior of Extension Personnel of State Department of Agriculture of Maharashtra State, India.International Journal of Current Microbiology and Applied Sciences. 